\section{B A Institute of \\ YK Business Administration \\ 六下 \\ Karachi \\ Leadership and Ideas for Tomorrow}

Business Review

Volume 8 Issue 2 July-December 2013

7-1-2013

\title{
The challenges of textile and manufacturing industries in Kano Metropolis
}

Ahmed Audu Maiyaki

Bayero University, Kano, Nigeria

Follow this and additional works at: https://ir.iba.edu.pk/businessreview

Part of the Business Commons, and the Fiber, Textile, and Weaving Arts Commons

(c) (i)

This work is licensed under a Creative Commons Attribution 4.0 International License.

\section{Recommended Citation}

Maiyaki, A. (2013). The challenges of textile and manufacturing industries in Kano Metropolis. Business Review, 8(2), 116-123. Retrieved from https://doi.org/10.54784/1990-6587.1290

This article is brought to you by iRepository for open access under the Creative Commons Attribution 4.0 License and is available at https://ir.iba.edu.pk/businessreview/vol8/iss2/9. For more information, please contact irepository@iba.edu.pk. 


\title{
ARTICLE
}

\section{The challenges of Textile and Manufacturing Industries in Kano Metropolis}

\author{
Ahmed Audu Maiyaki \\ Bayero University, Kano, Nigeria
}

\begin{abstract}
Industrialization is the engine of growth in any economy because it plays an important role in the provision of employment, foreign exchange earnings and general well being of a society. However, industrial growth is moving at a very slow rate in Nigeria and particularly in Kano state. This paper aims at unveiling the causes for poor performance of textile industry in Kano Nigeria In this study two textile companies were purposively chosen to represent both the functioning and non-function textile companies. To this end, structured and unstructured interviews and also practical observation were used to collect the data. It was found that grossly inadequate provision of basic infrastructure is main reason accounting for poor performance of textile industry in Kano, Nigeria.
\end{abstract}

Keywords: Manufacturing, Textile, Infrastructure, Kano, Nigeria.

\section{Introduction}

In spite of various macro and micro economic policy measures taken by the Nigerian government at different times, the industries in the country have not achieved impressive performance over the years. Thus, a sizeable number of manufacturing companies has closed down, while many others are struggling to survive. This resulted to the insignificant contribution of the sector to Gross Domestic Product (GDP) of the country. For instance, the sector accounted for only 6.4 percent of GDP (Sagagi, 2003). Similarly, capacity utilization of the sector has been persistently declining over the years (Anyanwu, Oyefusi, Oaikhenan, Domowo, 1997). This is in line with the observation by (Tybout, 2000), that some of the critical areas in which manufacturing industries in developing countries generally face serious challenges include: market size, access to manufactured input, infrastructure, plant size and scale efficiency among others.

Ironically some foreign investors like those from china and India operate in Nigeria comfortably and have their business flourishing. Many organizations in Nigeria and Kano in particular are either operating below capacity or have closed down completely due to external or internal problems they are faced with. The external problem include political/legal environment i.e. government policies that neglect the provision of infrastructural facilities such as power supply, good roads network water supply among others. Secondly, globalization leads to a stiff foreign competition, and Nigerian industries cannot compete effectively with their foreign counter part especially the textile industries. On the other hand internal problem comprise of managerial inefficiency, employee unrest, use of out dated machineries, local method of production, lack of diversification, and lack of research and development to mention just a few. For instance, 
Nigerians mostly depend on foreign technology to improve there manufacturing facilities (Oyelaran-Oyeyinka, Laditan \& Esubiyi, 1996).

Based on the aforementioned background therefore, this paper examine the reason(s) why local textile industries are folding up due to some problems while at the same time; the foreign textile manufactures operate in Nigeria with some degree of success.

\section{An Overview of the Manufacturing Sector in Nigeria}

Manufacturing sector plays an important role in the growth and development of any nation. In fact, the sector is considered as the edge of modernisation and skilled job creation, and hence, is often the darling of policy markers in the developing countries (Tybout, 2000). Manufacturing involves the conversion of raw materials into finished consumer, intermediate or producer goods. This is due to the fact that it generates employment opportunities, boast agriculture, diversify the economy, increase foreign exchange earning among others (Anyanwu et al, 1997).Furthermore, in classifying the manufacturing sectors, the following products in various sect oral groups are identified in Nigeria: Food, Beverages \& Tobacco; Chemical and Pharmaceuticals; Domestic and Industrial Plastic and Rubber; Basic Metal, Iron and Steel and Fabricated Metal Products; Pulp, Paper \& Paper Products, Printing \& Publishing; Electrical \& Electronics; Textile, Wearing Apparel, Carpet, Leather \& Footwear; Wood and Wood Products Including Furniture; NonMetallic Mineral Products; Motor Vehicle \& Miscellaneous Assembly (Mike, 2010).

Manufacturing industry in Nigeria has evolved through a number of stages and this evolution has started since before the country got independence and has continue to evolve till today. However, all the stages of development in manufacturing industry in Nigeria are faced with one problem or the other. An yawu et al. (1997) observe the nature of some problems with regards to Nigerian manufacturing industry as follows:

- Over dependence on foreign trade and import substitution during the period of colonial rule.

- Participation by government and exercising monopoly in the production of commodities such as: fertilizer, liquefied natural gas, steel etc. and also the attempt, by government to diversified into non-traditional products e.g. Petrochemicals.

- In the 1980s the economy faced dwindling revenue, due to the drastic falling of the petroleum product price in the international market. Again around mid 1980s Nigeria adopted an economic reform measure known as structural adjustment programmer (SAP), which subsequently leads to devaluation of naira, high exchange rate and high inflation rate. These developments further worsen the situation in the manufacturing sector.

All the above bottlenecks, perhaps negatively affected real sector more than any other sector because most of the manufacturing companies used to import raw materials at the moment. However, the impact of the SAP programme on the manufacturing industry and the economy at large is worth mentioning. Although some industries considered SAP programme as an opportunity while other saw it as a threat. According to Iyanda (2003), the results of SAP can be described as mixed at best and disastrous at worst. Even though, a major objective of the programme was to increase productivity, however, its adverse effects on the economy made cost efficiency and factor productivity impossible (Iyanda, 2003). Moreover, the effects of SAP were equally evident from the marketing perspectives. For example, the changes brought about by the programme resulted into a weakened consumer demand, increases price cognition, reduced 
preference for product/service quality (Iyanda, 2003). Generally, the consequential effects of SAP in the developing economies such as Nigeria and Zimbabwe are disastrous (Maiyaki, 2010).

According to CBN annual report and statement of accounts for various years as cited by Anyanwuet. al. (1997), some selected indicators of the manufacturing sub-sector in Nigeria between 1960 and 1995 were on the negative side. For instance, capacity utilization reached its peak in 1980 at $75 \%$ and then started coming down continuously (except for 1992 which increased marginally) till it reached $29.3 \%$ in 1995 . Another key indicator is import; the value of import in Nigeria between 1960 and 1995 on the other hand shows an annual increase (except for the marginal decrease in 1970) from \$1.1b in 1965 to N56.6b in 1995.

\section{Textiles Industry in Nigeria}

The Nigerian agro-allied sector is made up of various enterprises that provide inputs to several other sub-sectors in the economy. However, the situation of agro-based industry in Nigeriasuch as textile is that of old glory. Modern Nigeria was built on the revenue derived from key industries relating to cotton, groundnut, oil palm, rubber, cocoa among others. A large number of these companies have been reduced to mere signboards because most of the factories are closed down.

Textile industry is the most prominent agro-based industry which used to be next to public sector in terms of the number of employees. Thus, the industry has strong association for employers and employees. However, the recession in the industry has been rapid and devastating. The industry, which depends principally on the locally produced cotton, is in very poor state, in fact on the verge of collapse. The cotton locally produced can no longer sustain the textile industry. At a point in time cotton has to be imported from Burkina Faso to provide input for textile industry.

\section{Problems of Industries in Nigeria}

The Nigerian economy is characterized by over dependence on oil and neglecting other sectors of the economy, which are equally important in terms of GDP improvement and employment opportunities. For instance, before late 1970s the economy was mainly based on agriculture and it adequately employed two thirds of the whole population in addition to accounting for $41.84 \%$ of the GDP (Dandago \& Maiyaki, 2008; Mike, 2010). The possibility of Nigerian industries to make the necessary transition to avail themselves of the opportunities offered by the increasing integrated world trade system is questionable (Mike, 2010). This is because they are constrained by factors such as law-level of local purchasing power, lack of health and literate workforce, poor infrastructure and low capacity utilization, the stringent control on liquidity, variable higher interest rate coupled with substantially devalued currency and the unstable macro economic environment have negative effects on manufacturing industries (Tybout, 2000; Dandago \& Maiyaki, 2008).

With globalization today, world has become a borderless environment with free flow of goods, services, persons, capital, and ideas from one country to another. Nigerian economy has become relatively opened in compliance with GATT/WTO agreements. Other problems of industries in Nigeria are insufficient access to credit facilities (Malik, Teal \& Baptist, 2004). Thus, local investors cannot afford the huge capital needed in setting a world class standard manufacturing plant. Secondly, preference for foreign product by the local market, lack of effective strategic management in companies and lack of innovation are yet other set of problems 
(Tybout, 2000). Similarly, it has been observed that lack of linkages between small and medium scale industries forces domestic industries to engage in backward integration (Mike, 2010). This situation resulted in inefficient utilization of resources, which also affects its development.

Additionally, political instability, this scares away both local and foreign invertors because, industrialization does not take place in a politically rowdy atmosphere (Bala,2003). Similarly, Dandago \& Maiyaki (2008) observe that despite the huge resource base of the country, Nigeria has not been able to achieve a high level of economic growth, nor has it been able to attract a high level of Foreign Direct Investment (FDI) commensurate with its economic potentials. The consequential effect of this is inadequate flow of foreign direct investment (FDI) and poor export performance also contribute to the problems of the sector (Malik, Teal \& Baptist, 2004).Nigeria as a is third world country characterized by absence of developed markets, Nigeria's system of exchange is still underdeveloped and there is low demand as a result of low per-capita income which consequently leads to idle capacity (Malik, Teal \& Baptist, 2004).

Furthermore, Malik, Teal \& Baptist (2004) found that due to domestically oriented strategies adopted by local companies, Nigeria's total export of manufactured products/services insignificant. Inadequate skilled personnel can be attributed to our faulty educational system, which is inherited right from the colonial times. Tybout (2000) observes that low rate of secondary school education and inadequate technicians/scientist also affects the production process in the manufacturing industries. It has been observed that skill is an important determinant of earning and the level of workers' education is often considered as a proxy for skills (Malik, Teal \& Baptist, 2004).

Similarly, intermittent power supply is yet another major problem which brings the productive activities of industries to almost a halt. Hence, some industries are compelled to buy generators to support their operation, this leads to an increased in production cost and eventually results in increased product price. Hence, Malik, Teal \& Baptist (2004) concluded that by far the most significant problem of the physical infrastructure relates to unreliable and intermittent power supply; and that erratic power supply has become a fact of life for most manufacturers in Nigeria, who now increasingly rely on personal generators, voltage stabilizers and motors to keep their machines running. This therefore, significantly, raises the cost of production.

Furthermore, shift of ownership is another great problem of industries failure especially in the northern part of Nigeria. Most of the Kano based industries are sole proprietors owned by individuals, when the owner dies the ownership shift to his/her children. The involvement of the family in management usually leads to crisis between the family members, which eventually lead to closure of the firm.

On the basis of the foregoing, Nigeria's manufacturing industry could be considered as non-competitive in the international market. This is due to the failure of local industries to secure a competitive position in the world market. The concern however, is how to explore deliberate actions that could increase the industries participation in international market.

\section{Background of the Sampled Companies}

Bagauda Textile Mill, Bompai, Kano, was incorporated in 1971, as a limited liability company with Alhaji Isyaku Rabi'u as Chairman and majority shareholder, of the company. The factory was designed to produce various types of fabrics, namely; suiting, shirting, dress material, upholstery materials with different type of colours combination and woven designed. 
In late 1970s and early 1980s Bagauda Textile Mill successfully started producing uniform materials in various institutions as the best manufacturers specialized in blended suiting materials and this led to its award winning from Spain for quality in 1984. Additionally, Bagauda Textile Mill got technical know how "to produce high quality blended suiting materials, and was therefore, awarded contract to produce uniform materials for Army, Police, Navy, Air force, to mention a few. Bagauda Textile mill, owned the latest type of waving machine "SUIZER".

Northern Textile Manufacturers Limited (NTM) was established in 1962. NTM is a specialized textile manufacturer. They specialized on baby shawls and blankets. The company made a huge profit from 1965 to early 1980s. However, in the 1990s the company's productivity started going backward, year in year out, due to the macro and micro economic problems. The company is now under receivership, that is, it is being taken over by the bank they owe, until the bank recovers its money.

\section{Methodology}

\section{Research Questions}

1. Are macroeconomic factors such as interest rates, exchange rate, inflation and microeconomic factors the causes of industry closures in Kano?

2. To what extent does government policy and infrastructural deterioration bring about business closure in Kano?

3. Are there operational and business strategy problems (at financial) that contribute to the problems?

4. Is there a relationship between company closure and corporate leadership?

5. Is there any marketing problem that led to the present situation?

6. To what extent raw materials sourcing contribute the problem?

7. Is there any labor unrest that contributes to the problem?

In an attempt to answer the above questions, the authors used survey as their research design in this study. The population of the study is textiles industries that are located in Kano metropolis some which have been closed down, while some are struggling to survive and very few (if any) are operating to full capacity at moment of data collection. The sampling method used in the study is purposive Sampling, which is a non-probability sample selection method. Two textile Mills were purposively chosen to represent the population. One of them was closed down, i.e. Bagauda Textile Mills Kano and the Northern Textile Manufacturers is operating, but at below capacity. These two textile mills are used as the sample size of the study because data needed and the respondents were readily available. The data collection instrument adopted by the researchers was a structured interview. The research questions above are the question used for the interview. Documentary source of data or rather the secondary data was also used.

\section{RESULTS AND DISCUSSION}

In this section, the authors present the data obtained from the field, that is from Bagauda Textile and Northern Textile Manufacturers limited. Basically, the data involves structured interview with some of the key management staff as well as some junior staff of the companies. Consequently, an attempt was made by the authors to analyze the data obtained qualitatively. 
Based on responses by the respondents it could generally be concluded that macroeconomic factors significantly contribute to the failure of textile industry in Kano.This is so, because according to the respondents most of the chemicals they used and spare parts of the machineries are imported, and at the same time the exchange rate is high. Similarly, the high interest rate in the country also hinders the manufacturers from borrowing from financial institutions. With high interest rates they may not be able to get profit out yet.

Similarly, shortage of power supply significantly contributes to the failure of the manufacturing companies. Provision of basic infrastructures in the country is generally inadequate. For example, power supply is epileptic, thus, almost all manufacturing enterprises rely on alternative power supply mostly using generating sets which further increase the cost of production (MAN report, 2006). The report also revealed that the "Industrial estates within Kano: Sharada, Challawa, Kano Bompai were worst hit, with average power outages of 15 hours, 10.3 hours and 17.2 hours for January (2006) respectively. However, in March the outage figures aggravated to 17.6 hours, 13.0 hours and 18.5 hours respectively.

Similarly, despite the fact that water supply is very essential in industrial development, pipe bone water is lacked in the manufacturing industries. Given that textile plants can not do without water, this forced the organizations to drill boreholes in their premises that will supply them enough water. Some of the companies visited have between two to four boreholes and the maintenance further increases cost of operations. According to the respondents, lack of good road network contributes so much to the failure textile industry in Kano. This is because the access to raw materials is very poor. Similarly, for the imported materials to be transported from Lagos (sea port) to Kano is another problem which leads to higher cost of production.

When asked on whether there was any government policy that affected textile industry negatively, a management staff in one of the companies admits that high rate of tax by different level of government seriously affects their business negatively. In some instances the companies experienced multiple tax which leads to drastic reduction in their operation income and subsequently their inability to cover production cost. However, the respondents stressed that the fact that the banning of fabric materials importation if effectively implemented by government will significantly assists the local textile industry against foreign competition.

Based on the interview conducted it was also found that seasonality of the textile market also contributes to the problems in the industry. This is because during the off peak period the industry's income is very low.

About the relationship between the companies' leadership and company failure, one of the respondents said that inexperienced leaders significantly contribute to the falling down of their company. The respondents hold that subjective appointment of managing director not based on qualification eligibility was part of the companies' problems. According to him inexperienced chief executive would not be able to control cost and quality among others which are vital in terms of profit maximization and competition.

Again when asked about marketing problem the respondents agreed that preference mentality by the local consumers greatly affected the locally manufactures goods adversely. Therefore, most Nigerians prefer foreign products more especially the textile materials even if the locally manufactured one is of high quality. 
On whether the raw materials constitute a problem to the textile companies, Northern Textile Limited do not have problem in sourcing raw materials. This is due to the fact their product is special as such they use waste which according to the General Manager is readily available. However, all companies covered by the study emphasize the difficulty in procuring "Black oil" fuel which has to be imported a thigh cost.

\section{FINDINGS}

The authors arrived at the following as major finding of the research:

Firstly, lack of entrepreneurship orientation on the part of our local business men. The business people that can invest in industry to make money do not have the zeal to invest. This is because most of them are risk averters and therefore, they prefer business that has short gestation period (quick return).

Secondly, lack of managerial skill and/or qualification is yet another problem that causes the coming down of textile business in Kano. In some cases people without qualification and/or managerial skill are put at the driver's seat of the organizations. And the Chief Executive that has not got the basic qualification or skill ends up worsening the situation.

Similarly, lack of infrastructures facilities is the issue that was repeated by respondents as one of the major problems faced by the textile industry. Infrastructures such as power supply, pipe bone water, road networks are grossly lacking, by the companies studied. This is consistent with the findings by Malik, Teal \& Baptist (2004).

All the companies studied are limited liability companies either owned by a single individual or by few individual. And this greatly contributed to collapsing of the companies. Closelyrelated to this is the issue of family disagreement whereby due to misunderstanding by members of the family that owned a particular company, it spills over to the company's operation.

The above findings are all in line with what Tybout (2000) suggested as some of the bottlenecks militating against the growth of manufacturing sector in the developing countries visà-vis its counterpart in the technologically developed countries.

\section{RECOMMENDATIONS:}

In line with the above findings, policy makers are recommended to:

- Expand and facilitate entrepreneurship education through redesigning school curriculum.

- Adequately provide the basic infrastructure such as pipe borne water, electricity, good road network.

- $\quad$ Provide enabling environment that would attract foreign direct investment (FDI).

\section{CONCLUSION}

Lack of basic infrastructures facilities such as power supply, pipe-bone water, road network played the role in putting our textile industry into a chaos situation. However, the most significant factors are lack of entrepreneurship zeal by our local investors, lack of qualification and managerial skills by the key management staffs; lack of enough capital, and the problem of sole ownership. This category of problem appears to have significant importance in blocking the development of textile industry in Kano. Similarly, inability of our local industry to stand the test of global competition is another factor that contributes to the downfall of our textile industry. However, critical analyses into the above issues that the respondents considered to be the 
problems that led to the collapse of textile industry in Kano, most of them are not actually the problems that are really beyond the capability of the local entrepreneurs. This can be justified when we consider the fact that Chineese, Indians and Lebanees manufacturers operate in the same business environment successfully despite the so-called problems claimed by our local manufacturer. 粟

\section{References}

Anyanwu, J.C., Oyefusi, A., Oaikhenan, H., Domowo, F.A. (1997). The structure of the Nigerian Economy (1960-1997). Joanee Educational Publisher Limited, Onitsha, Nigeria.

Bala, J.J. (2003). The challenges and opportunities of the investment environment in Nigeria. A Paper presented at the international meeting for the promotion of investment toAfrica organised by the ministry of foreign affairs of Japan, held at Mita, Tokyo, February, 2003

Iyanda, O. (2003). The structural adjustment programme and marketing in the manufacturing industry in Nigeria. Management Decision, 41, 3, 250-256

Dandago, K. I. \& Maiyaki, A. A. (2008). State governments and the war against poverty in Nigeria. In M. C. Duze, H. Mohammed \& I. A. Kiyawa (Eds.), Poverty in Nigeria: Causes, manifestations and alleviations strategies. London: Adonis \& Abbey Publishers Ltd

Maiyaki, A. A. (2010). Zimbabwe's agricultural industry.African Journal of Business Management, Vol. 4(19), pp. 4159-4166,

http://www.academicjournals.org/AJBM

Malik, A., Teal, F. \& Baptist, S. (2004). The Performance of Nigerian Manufacturing Firms: Report on the Nigerian Manufacturing Enterprise Survey. An unpublished report at Centre for the Study of African Economies, University of Oxford, OX1 3UQ, UK Manufacturers' Association of Nigeria (MAN), (2006). Nigeria: MAN set to own Independent Power Plants (IPPS). Retrieved on 15/07/2006 from http://allafrica.com/stories/200607/30350.html,

Mike, J.A. (2010). The structure of the Nigerian manufacturing industry. A paper at the national workshop on strengthening innovation \& capacity building in the Nigerian manufacturing sector, held at Sheraton Hotel and Towers, Lagos, Nigeria in July 2010.

Oyelaran-Oyeyinka, B., Laditan, G.O.A. \& Esubiyi, A.O. (1996).Industrial innovation in SubSaharan Africa: The manufacturing sector in Nigeria.Research Policy, 25, 1081-1096

Sagagi M.S. (2003). World Trade Organisation and the Competitiveness of the Nigerian Manufacturing Industry. Bayero Business Review, vol. 1, No 1, October, 2003, pp 1-14.

Sudeshna, G.B. Jennifer, M.O. Rupa, R. (2006) . Private Provision of Infrastructures in Emerging Markets; Do Institutions Matter? Development Policy Review, vol, 24, No 2, Black well Publishing, Oxford. Pp 175-202.

Tybout, J. R. (2000). Manufacturing Firms in Developing Countries: How Well Do They Do, and Why? Journal of Economic Literature, Vol. 38, No. 1, pp. 11-44

Vincent, P. (2005). Industry level analysis: the way to identify the binding constraints to economic growth, World Bank Publications, Volume 3551 of Policy research working papers 